\title{
The Relation Of Total Cholesterol And Triglyceride Levels Toward Hypertension Among Sampara Subdistrict Community
}

\author{
I Putu Sudayasa ${ }^{1}$, La Ode Muhammad Novriyanto Ruslan², Apriadin La \\ Ode Dane $^{3}$, Jamaluddin Jamaluddin ${ }^{4}$ \\ \{dr.putusudayasa@uho.ac.id ${ }^{1}, 1 . m n o v r i y a n t o r u s l a n @ y a h o o . c o . i d^{2}$, \\ apriadinlaode@gmail.com $\left.{ }^{3}\right\}$ \\ 1,2,3,4 Medical Faculty, Halu Oleo University, Kendari, Indonesia
}

\begin{abstract}
High level of total cholesterol and triglyceride can cause hypertension. This research aimed to analyze the relation of total cholesterol and triglyceride levels as risk factor for hypertension among Sampara District of Konawe community. This research was analytical observational with case control design. Population was peoples of Sampara Subdistrict, Konawe, that consume pokea shell. Sample of research were 70 samples with purposive sampling method. Data was collected with blood examination and sphygmomanometer mercury. Data was analyzed by Odds Ratio (OR). Statistically, OR value that obtained were total cholesterol level ( $\mathrm{p}$-value $=0,001, \mathrm{OR}=5,455 ; \mathrm{CI}$ $95 \%=1,960-15,176)$ and triglyceride level ( $\mathrm{p}$-value $=0,003, \mathrm{OR}=4,750 ; \mathrm{CI} 95 \%=$ $1,642-13,740)$. Conclusions of this research, there were relation of cholesterol total and triglyceride level toward hypertension among Sampara Subdistrict community.
\end{abstract}

Keywords: Hypertension, Total Cholesterol, Triglyceride, Pokea Shell, Sampara Subdistrict.

\section{Introduction}

Hypertension is a global problem because its prevalence continues to increase and it is estimated that in 2025 around $29 \%$ of adults world wide will suffer from hypertension. Based on data from American Heart Association, of 59\% of hypertensive patients in America only $34 \%$ are controlled, while $25 \%$ of adults suffer from hypertension. Hypertension is a condition of increasing systolic blood pressure more than $140 \mathrm{mmHg}$ and diastolic more than or equal to $90 \mathrm{mmHg}$ [1]. In general, hypertension is an asymptomatic condition, where high blood pressure in the arteries causes an increased risk of cardio vascular related diseases such as stroke, kidney failure, heart attack, and kidney damage [2]. Based on data from the Non Communicable Disease Watch, 2018, more than 20\% of adults world wide have increased blood pressure, a condition that causes about half of all deaths from strokes and heart disease. [3]. Hypertension is a controlled risk factor for stroke, and is estimated to affect $25 \%$ to $50 \%$ or increase the risk of 3-4 times the incidence of stroke compared to not hypertension. Hypertension every year kills 9 million people worldwide and in Southeast Asia almost 1.5 million people. About one third of the adult population in Southeast Asia suffer from hypertension. The prevalence of hypertension in Indonesia reaches $25.8 \%$, higher than the prevalence of hypertension in several other countries, such as Singapore $(14.1 \%)$, Thailand $(22.3 \%)$, and Malaysia (22.1\%) [4]. 
The prevalence of $6-15 \%$ in adults, $50 \%$ of whom are not aware of being hypertensive so they tend to become severe hypertension because they do not avoid and do not know the risk factors, and $90 \%$ are essential hypertension. At present degenerative and cardio vascular diseases are already one of the public health problems in Indonesia [5]. Complications of hypertension cause 9.4 million deaths worldwide 1.5 million deaths per year in the Southeast Asia region. The prevalence of hypertension in Indonesia obtained through measurements at the age of sebesar18 years was $25.8 \%$, the highest in Bangka Belitung (30.9\%), followed by South Kalimantan (30.8\%), East Kalimantan (29.6\%) and Java West (29.4\%). The number of hypertension cases in Southeast Sulawesi is still relatively high and ranks as the second highest disease [6].

Cholesterol can come from daily food as exogenic cholesterol and which is synthesized in the body as endogenic cholesterol. The prevalence of hypercholesterolemia in Indonesia, at the age of 25-34 years is $9.3 \%$, whereas at the age of $55-64$ years it is $15.5 \%$. The incidence of hypercholesterolemia in the MONICA I (Multinational Monitoring of Trends Determinants in Cardiovascular Disease) study amounted to $13.4 \%$ of women and $11.4 \%$ of men. Monica II obtained increased to $16.2 \%$ for women and $14 \%$ for men [7].

Fats in food substances generally consist of three fatty acid groups with glycerol known as triglycerides. Triglycerides are one type of fat found in the blood and various organs of the body. Triglycerides are formed from glycerol and fat derived from food with insulin stimulation or excess calories from overeating. Excess calories will be converted into triglycerides and stored as fat under the skin [8].

Communities around the Pohara River, Sampara District, Konawe Regency, Southeast Sulawesi, make pokea shells (Batissa violacea celebensis Marten 1897), as a source of livelihood and are traded in the form of fresh whole, fresh peeled, and satay. Pokea clams are used by local people to be consumed daily by boiling. The fatty acid composition in fresh and boiled pokea shellfish was identified as 27 types of fatty acids consisting of 12 types of saturated fatty acids (SFA), 6 types of monoun saturated fatty acids (Monoun saturated fatty acids (MUFA), and 9 types of polyunsaturated fatty acids or Polyunsaturated fatty acids (PUFA). MUFA and PUFA contents have an important role in reducing cardio vascular disease, type 2 diabetes, inflammatory disease, and autoimmune disorders [9].

The results of the study in 2018 showed that the consumption pattern of pokea shellfish had an effect on the state of blood pressure in the Sampara Subdistrict community [10]. This study aimed to analyze total cholesterol and triglyceride levels with the incidence of hypertension in the Sampara Subdistrict community, Konawe Regency, Southeast Sulawesi.

\section{Method}

The study design was analytic observational case control with a retrospective approach. This research was conducted in Sampara Subdistrict, Konawe Regency, namely Andadowi Village, Pohara Village and Sampara Village in September-December 2018. The sampling technique used was purposive sampling method with a sample of 70 samples (35 cases of hypertension, 35 controls instead of hypertension). Primary data was obtained from the results of blood pressure checks, and venous blood collection for examination of total cholesterol and triglyceride levels. Secondary data regarding the incidence of hypertension were obtained from Sampara Health Center. Data analysis using statistical tests, p-value and Odds Ratio (OR). This research has received approval from the Health Research Ethics Commission, Halu Oleo University Research and Community Service Institution. 


\section{Result}

Data on the relationship of total cholesterol with the incidence of hypertension in the Sampara community can be seen in Table 1 .

Table 1. Relation of Total Cholesterol Levels with Hypertension Events in Pohara Coastal Community, Sampara Subdistrict, Konawe Regency

\begin{tabular}{|c|c|c|c|c|c|c|c|c|}
\hline \multirow{3}{*}{$\begin{array}{l}\text { Cholesterol } \\
\text { Total Level }\end{array}$} & \multicolumn{4}{|c|}{ Hypertension } & \multirow{3}{*}{$\mathrm{p}$-value } & \multirow{3}{*}{ OR } & \multicolumn{2}{|c|}{$95 \% \mathrm{CI}$} \\
\hline & \multicolumn{2}{|c|}{ Case } & \multicolumn{2}{|c|}{ Control } & & & $\mathrm{I}$ & H \\
\hline & $\mathrm{n}$ & $\%$ & $\mathrm{n}$ & $\%$ & & & LL & UL \\
\hline Not Normal & 25 & 35,7 & 11 & 15,7 & & & & \\
\hline Normal & 10 & 14,3 & 24 & 34,3 & 0,001 & 5.455 & 1,960 & 15,176 \\
\hline Total & 35 & 50 & 35 & 50 & & & & \\
\hline
\end{tabular}

The results of the data analysis of 70 respondents, showed that in the hypertension group there were 25 people (35.7\%) respondents who had total abnormal cholesterol, and 10 people $(14.3 \%)$ respondents who had normal total cholesterol levels. In the non-hypertensive group, there were 11 people $(15.7 \%)$ respondents who had abnormal total cholesterol levels and 24 people $(34.3 \%)$ respondents, had normal total cholesterol levels. Based on table 1, it is known that the results of statistical tests show that there is a significant relationship between total cholesterol levels and the incidence of hypertension in coastal communities in Pohara, Sampara Subdistrict, Konawe Regency. The statistical test results obtained $p=0.001$, the value of Odds Ratio $=5.455 ; \mathrm{CI}=95 \%(1,960-15,176)$, which indicates that there is a relationship between total cholesterol levels and the incidence of hypertension in the coastal communities of Pohara, Sampara Subdistrict, Konawe Regency.

Table 2. Relation of Triglyceride Levels with Hypertension in Pohara Coastal Community, Sampara Subdistrict, Konawe Regency

\begin{tabular}{|c|c|c|c|c|c|c|c|c|}
\hline \multirow{3}{*}{$\begin{array}{l}\text { Triglyceride } \\
\text { Level }\end{array}$} & \multicolumn{4}{|c|}{ Hypertension } & \multirow{3}{*}{ p-value } & \multirow{3}{*}{ OR } & \multicolumn{2}{|c|}{$95 \% \mathrm{CI}$} \\
\hline & \multicolumn{2}{|c|}{ Case } & \multicolumn{2}{|c|}{ Control } & & & J & tII \\
\hline & $\mathrm{n}$ & $\%$ & $\mathrm{n}$ & $\%$ & & & LL & UL \\
\hline Not Normal & 19 & 27,1 & 7 & 10,0 & & & & \\
\hline Normal & 26 & 22,9 & 28 & 40,0 & 0,003 & 4,75 & 1,642 & 13,74 \\
\hline Total & 35 & 50 & 35 & 50 & & & & \\
\hline
\end{tabular}

Based on table 2, the results of data analysis showed that of 70 respondents, in the hypertension group there were 19 people $(27.1 \%)$ respondents who had abnormal triglyceride levels, and 16 people $(22.9 \%)$ respondents who had normal triglyceride levels. Whereas in the group that did not suffer from hypertension there were 7 people $(10.0 \%)$ respondents who had abnormal triglyceride levels and 28 people $(40.0 \%)$ respondents who had normal triglyceride levels. The results of statistical tests, the value of $\mathrm{p}=0.003$, Odds Ratio of $4.75 ; \mathrm{CI}=95 \%$ $(1,642-13,740)$ shows there is a relationship between triglyceride levels and the incidence of hypertension in coastal communities of Pohara, Sampara Subdistrict, Konawe Regency. 


\section{Discussion}

The results of this study, showed that respondents had abnormal total cholesterol levels $51.4 \%$, while those with normal cholesterol levels were $48.6 \%$. As many as $71.4 \%$ of the case respondents had abnormal total cholesterol and $27.1 \%$ had abnormal triglyceride levels. The proportion of total cholesterol and triglyceride levels, which varies, is that there is a habit of consuming high-fat foods, as well as other food sources consumed, containing high cholesterol levels, in addition to pokea.

This research was in line with the theory which states that high cholesterol levels play a role in the occurrence of hypertension. Cholesterol has a dual function, which on the one hand is needed and on the other hand is dangerous, depending on how much is in the body and where it accumulates. Cholesterol if present in too much amount can cause constriction called atherosclerosis. When narrowing occurs in the heart blood vessels can cause coronary heart disease and if the cerebral blood vessels cerebro vascular disease. The formation of atherosclerotic plaques will cause an increase in vascular resistance which can then cause hypertension, excessive fat consumption can pose a risk of hypertension because it will increase cholesterol levels in the blood [11].

Cholesterol will be attached to the walls of blood vessels which over time will clog the blood vessels due to the presence of plaque in the blood called atherosclerosis. Plaque that is formed will cause the blood flow to narrow so that blood volume and blood pressure will narrow so that blood volume and blood pressure will increase [12]. This study is in line with Harefa (2017) who stated that there is a correlation between cholesterol levels and the degree of hypertension, in hypertensive patients in the working area of Hiliwito Gido Health Center, Nias Regency [13]. The results of the research by Maryati (2017) also stated that there was a correlation between cholesterol levels and blood pressure in patients with hypertension in Sidomulyo Hamlet, Rejoagung Village, Ploso District, Jombang Regency [14]. Whereas Ulfah's research, in 2017, found a significant correlation with the weak correlation between total cholesterol levels and systolic blood pressure [15].

The results of this study was in line with Feriyadi's research, which based on the results of the independent sample t-test showed that there were significant differences between triglyceride levels of hypertensive people with normotension. While the results of the chisquare statistical test obtained a value of $p=0.04$ with a value of $\mathrm{OR}=2.49$, this indicates a significant relationship between triglyceride levels and the incidence of hypertension. Triglycerides are a risk factor for hypertension in the Minangkabau ethnic community in Padang at 2.49 times [8]. This research was in line laso, with the results of a study conducted by Darmastono, 2009, which states that there was a significant relationship between triglyceride levels and the incidence of both systolic and diastolic hypertension in SMAN 8 Semarang employees [16].

\section{Conclusion}

There were a correlation between total cholesterol and triglyceride levels with the incidence of hypertension in the Sampara Subdistrict community, Konawe Regency, Southeast Sulawesi.

For health agencies, need to carrying out health promotion and extension programs about hypertension risk factors. For the community, need to routinely examine blood pressure and cholesterol levels and familiarize a healthy lifestyle by limiting high cholesterol food intake. For other researchers, can conduct cohort research design for more accurate research results are obtained. 
Acknowledgements. Thank you very much for all respondent, public health centre officer, reasearch team, to finished this reasecch.

\section{References}

[1] American Heart Association (AHA), "Heart Disease and Stroke Statistics 2018, At-aglance", 2018. https://healthmetrics.heart.org/wp-content/uploads/2018/02/At-A-GlanceHeart-Disease-and-Stroke-Statistics-2018.pdf accessed March 20, 2019.

[2] Yonata, A., Pratama, A. S. P. Hipertensi Sebagai Faktor Pencetus Terjadinya Stroke. Majority. Volume 5. Nomor 3. Fakultas Kedokteran Universitas Lampung, 2016.

[3] Non Communicable Diasease Watch (NCDW), Hypertension: A Burning Health Problem, 2018. https://www.chp.gov.hk/files/pdf/ncd_watch_july_2018.pdf accessed March 20, 2019.

[4] Riyadina, W., Kodim, S. Trigliserida Sebagai Faktor Prognosis Untuk Hipertensi Tidak Terkendali Pada Wanita Pasca Menopause di Kota Bogor, Tahun 2014. Buletin Penelitian Kesehatan, 45(2): 2, 2017.

[5] Sanjaya, I Made A. W. Prevalensi Hipertensi Pada Penduduk Umur 30 Tahun Hingga 80 Tahun di Kecamatan Tembuku Bangli Bali Tahun 2013. E-jurnal Medikal, 5 (6): 2, 2013.

[6] Dinas Kesehatan Provinsi Sulawesi Tenggara. Profil Kesehatan Sulawesi Tenggara Tahun 2017. Dinas Kesehatan Sulawesi Tenggara. Kendari, 2018.

[7] Naue, S.H., Doda, V., Wungouwe, H. Hubungan kadar kolesterol total dengan tekanan darah pada guru di SMP 1 dan 2 Eben Haezar dan SMA Eben Haezar Manado. Jurnal eBiomedik (e-Bm). Volume 4. Nomor 2, Juli-Desember, 2016.

[8] Feryadi, R., Sulastri, D., Kadri, H. Hubungan Kadar Profil Lipid dengan Kejadian Hipertensi pada Masyarakat Etnik Minangkabau di Kota Padang Tahun 2012. Jurnal Kesehatan Andalas 3(2): p.206-211, 2014.

[9] Yenni., Nurhayati, T., Nurjanah. Pengaruh Rebusan Terhadap Kandungan Asam Lemak dan Kolesterol Kerang Pokea (Batissa violacea celebensis Marten 1897). JPHPI. Volume 15. Nomor 3. Program Studi Teknologi Hasil Perikanan Fakultas Perikanan dan Ilmu Kelautan Universitas Muhammadiyah Kendari, 2012.

[10] Sudayasa, I. P., Halim, N. A. H., Purnama, S. N. A., Ruslan, L. O. M. N., Kurniati., I. Pengaruh Konsumsi Daging Kerang Pokea (Batissa violacea celebensis) Terhadap Tekanan Darah Pada Masyarakat Pesisir Pohara, Prosiding Seminar Nasional Teknologi Terapan Berbasis Kearifan Lokal (SNT2BKL), ISBN: 978-602-71928-1-2, hal.515-522, 2018.

[11] Wongkar, M. C., Kepel, B. J., Hamel, R. S. Hubungan Status Gizi Dengan Kadar Kolesterol Total Pada Masyarakat Di Kelurahan Bahu Kecamatan Malalayang Manado. Program Studi Ilmu Keperawatan Fakultas Kedokteran Universitas Sam Ratulangi, e journal keperawatan (e-Kp), vol. 1. nomor 1, tahun 2013, hal.1-7, 2013.

[12] Ismuningsih, Rita. Pengaruh Konsumsi Lemak terhadap Tekanan Darah Penderita Hipertensi Rawatt Jalan di Rumah Sakit PKU Muhammadiyah Surakarta, 2013. http://eprints.ums.ac.id/27224/14/NASKAH_PUBLIKASI.pdf accessed March 20, 2019.

[13] Harefa, M.V. Hubungan Kadar Kolesterol Dengan Derajat Hipertensi Pada Penderita Di Wilayah Kerja Puskesmas Hiliwito Gido, Kabupaten Nias. Fakultas Kesehatan Masyarakat Univesrsitas Sumatera Utara Medan, 2017. http://repositori.usu.ac.id/handle/123456789/1643 accessed March 20, 2019. 
[14] Maryati. H. Hubungan Kadar Kolesterol dengan Tekanan Darah Penderita Hipertensi di Dusun Sidomulyo Desa Rejoagung Kecamatan Ploso Kabupaten Jombang, e-journak umm.ac.id, P-ISSN: 2086-3071, E-ISSN: 2443-0900, Volume 8, Nomor 2, Juli 2017, p.128-136, 2017.

[15] Ulfah, M., Sukandar, H., Afiatin. Hubungan Kadar Kolesterol Total dengan Tekanan Darah Pada Masyarakat Jatinangoor, JSK, Volume 3 Nomor 2, Desember Tahun 2017, p.58-64, 2017.

[16] Darmastono P. Hubungan Antara Persentasi Lemak Tubuh, Lingkar Pinggang, Kolesterol Total Dalam Darah dan Trigliserida Dengan Tekanan Darah (Studi Pada $\begin{array}{llllll}\text { Pegawai Negeri Sipil SMA } 8 & \text { Semarang), } & 2009 .\end{array}$ http://eprints.undip.ac.id/25028/1/222_Punto_Darmastomo_G2C005297_A.pdf accessed March 20, 2019. 